\title{
Opportunities for Kaizen in Africa: Developing the Core Employability Skills of African Youth Through Kaizen
}

\author{
Momoko Suzuki and Eriko Sakamaki
}

\section{INTRODUCTION}

Kaizen seems to be expanding its reach across Africa. While it was originally introduced as an approach to improve organizational management by enhancing quality and productivity in the workplace, several African countries have noticed the favorable impact of Kaizen on core employability skills' development and have started to introduce it into their education sectors-in particular through technical and vocational education and training (TVETs) and universities.

In Ethiopia, TVETs are providing Kaizen training to enhance student attitudes toward work. This is a common course for all TVET students. In South Africa, universities of technology have introduced Kaizen training and are offering it in all departments. In these two countries, Kaizen is

\footnotetext{
M. Suzuki (四)

Industrial Development and Public Policy Department, Japan International Cooperation Agency, Tokyo, Japan

e-mail: Suzuki.Momoko@jica.go.jp

E. Sakamaki

Japan Overseas Cooperation Volunteers, Japan International Cooperation Agency, Tokyo, Japan

(C) The Author(s) 2020

A. Hosono et al. (eds.), Workers, Managers, Productivity, https://doi.org/10.1007/978-981-15-0364-1_7
} 
seen as an approach to enhance core employability skills. Other countries such as the Democratic Republic of Congo and Senegal are also introducing Kaizen in TVETs.

While the scale and progress of introducing Kaizen into the educational sector differ between countries, the objective is common-to enhance students' capacity in preparation for joining the workforce. The United Nations has projected that the African continent's population will double by 2050 (UN DESA 2019). Considering the small size of the private sector, absorbing the increasing working age population within the currently restricted labor market will be almost impossible. Furthermore, many CEOs feel that new graduates do not have the basic skills needed in the workplace (Aring 2012). Creating job opportunities as well as developing the skills that meet the needs of the labor market is crucial for Africa's sustainable development.

This chapter explores how Kaizen has been integrated into education systems in African nations and how it creates opportunities to enhance the core employability skills of graduates. We first discuss the definition of employability and core employability skills, followed by an examination of the relationship between the Kaizen approach and the enhancement of core employability skills. In later sections, we look at two countries where Kaizen has been introduced, Ethiopia and South Africa. The former has introduced Kaizen into TVETs and the latter into universities. These cases demonstrate how Kaizen has been introduced along with the impacts and lessons learned so far.

\section{Defining and Categorizing Core Employability SKILLS}

\subsection{Definition of Employability}

The concept of employability, as promulgated in the late 1990s (see ILO 2000; UN 2001), was driven by the awareness of a shift in the world toward knowledge and skill-based economies and societies. The International Labour Organization (ILO) report (2000) examined how globalization, technological advancement, and new organizational management have impacted on the labor market, leading to shifts in the skills required, and resulting in unstable and insecure employment. The literature regarding employability argues that current education and training 
systems remain largely unrelated to labor market needs and, therefore, the "skills gap" between graduates of education systems and the labor market is widening. However, there seems to be a variation in the definition of employability and the elements that constitute it.

Hillage and Pollard (1998) define "employability" as having the capacity in terms of knowledge (what they know), skills (what they do with the knowledge), and attitudes (how they do it) to gain initial employment, maintain employment, and obtain new employment if required. The ILO's definition puts more emphasis on the changing world of work and characterizes employability as "portable competencies and qualifications that enhance an individual's capacity to make use of the education and training opportunities available in order to secure and retain decent work, to progress within the enterprise and between jobs, and to cope with changing technology and labor market conditions" (ILO 2004, Recommendation 195). Yorke $(2006,3)$ sees employability as a set of achievements that impacts not only oneself but also society. He defines "employability" as "a set of achievements—skills, understandings and personal qualities - that makes individuals more likely to gain employment and be successful in their occupations, which benefits themselves, the workforce, the community and the economy." He deliberately uses the words "understandings" and "personal qualities" instead of "knowledge" and "attitude" to signal the importance of a rich appreciation of the relevant fields.

From the definition above, it seems fair to say that employability is an individual's capacity (or competencies, or a set of achievements) that enables them to gain a job and progress in their career and successful life. Employability should be transferrable across sectors and malleable to changing technologies. Yorke (2006) also points out the significance of metacognition in employability. Metacognition encompasses selfawareness and the capacity to reflect on one's learning. It is especially important if individuals seek to progress their career in the modern world where technology and the environment surrounding the labor market rapidly change.

Furthermore, the three definitions indicate that individuals are most employable when they have appropriate knowledge (understanding), skills, and attitudes (personal qualities). In this chapter, we call these three competencies-knowledge, skills, and attitudes-the competencies for employability. 
Yorke (2006) argues that employers are more or less satisfied with subject-specific knowledge, skills, and attitudes as a consequence of broad-based education, but they are less content with generic skills like communication, teamwork, and time management. While Yorke's argument is based on the labor situation in the United Kingdom, other literature regarding employability suggests that similar skill gaps exist in other areas of the world (METI 2006, 2007; Brewer 2013; British Council 2014). In this chapter, where this gap is identified, we refer to these generic skills as "core employability skills."

\subsection{Core Employability Skills}

Core employability skills are built upon and strengthen those developed through basic education, such as reading and writing (knowledge), technical skills needed to perform specific duties (skills), and personal qualities such as honesty, reliability, and time management (attitudes) (Brewer 2013). They overlap with other competencies (knowledge, skills, and attitudes) and develop through a spiraling process by interacting with one another through an individual's various experiences (METI 2006).

While much attention has been given to core employability skills by the labor market, government policy has long overlooked their importance. These skills are often not certified nor formally recognized (Brewer 2013).

Yorke and Knight (2006) attempt to identify and categorize aspects of core employability skills in order to embed them into school curriculums. They divide aspects of core employability skills into three categories: core skills (relating to knowledge and understanding), process skills (relating to skills), and personal qualities (relating to attitudes). A total of 39 aspects are listed. Twelve aspects are listed under core skills such as reading and writing, numeracy, information retrieval as well as self-management, creativity, and critical analysis. Seventeen aspects are identified as process skills, including problem-solving, teamwork, negotiation, and planning. Ten aspects are listed under personal qualities, such as self-awareness, selfconfidence, and willingness to learn, as well as emotional intelligence, adaptability, stress tolerance, and reflectiveness. Yorke and Knight's listing contributes to the understanding that, even within core employability skills, there are multiple aspects, thus making it difficult to grasp what the core employability skills are.

Brewer (2013) pools skills and abilities that consistently appear in employer surveys and various documents and categorizes them into four 
broad skill categories: learning to learn, communication, teamwork, and problem-solving. While the list is not exhaustive, it points out the skills that are valued across sectors and nations.

Learning to learn refers to the ability to pursue and persist in learning and to be able to organize one's learning, including effective management of time and information, both individually and in groups. Skills such as self-awareness, self-management, and willingness to learn are all related to learning to learn.

Communication skills means being able to articulate one's thoughts using written, verbal, and non-verbal communication methods. One also needs to be able to listen and read, understand the context, interpret the world, and relate to others.

\section{Core Employability Skills in Africa}

While the skills gap has been one of the main development challenges in Africa for some time, the importance of core employability skills has not been fully acknowledged by policymakers. More interest has been focused on enhancing the quality of basic education and improving enrollment rates in secondary and tertiary education.

Studies show that $80 \%$ of Malian third graders and more than $70 \%$ of Ugandan third graders are illiterate (Cloutier et al. 2011). Only 26\% of students in South Africa meet the Program for International Students Assessment (PISA) standard (World Bank 2019). Furthermore, the gross enrolment ratio in higher education is only $8.17 \%$ in sub-Saharan Africa (the global average is $32.88 \%$ ), so it is not difficult to understand why this remains the highest priority.

However, this does not mean that core employability skills are not important in the labor markets of Africa. Although there are widespread concerns regarding the work readiness of graduates, there are very few studies that have investigated the specific skills that employers see as the gaps. One study conducted by the South Africa Graduate Recruiters Association (SAGRA) in 2013 demonstrated that core employability skills do actually matter (Fig. 7.1). The study shows that employers consider willingness to learn, teamwork, communication, and problem-solving to be some of the most important skills that graduates should have, and yet employers are not satisfied with employee abilities in these areas. Employers also feel that interpersonal skills, commitment, and proactivity are some key areas where there is a skills gap. 


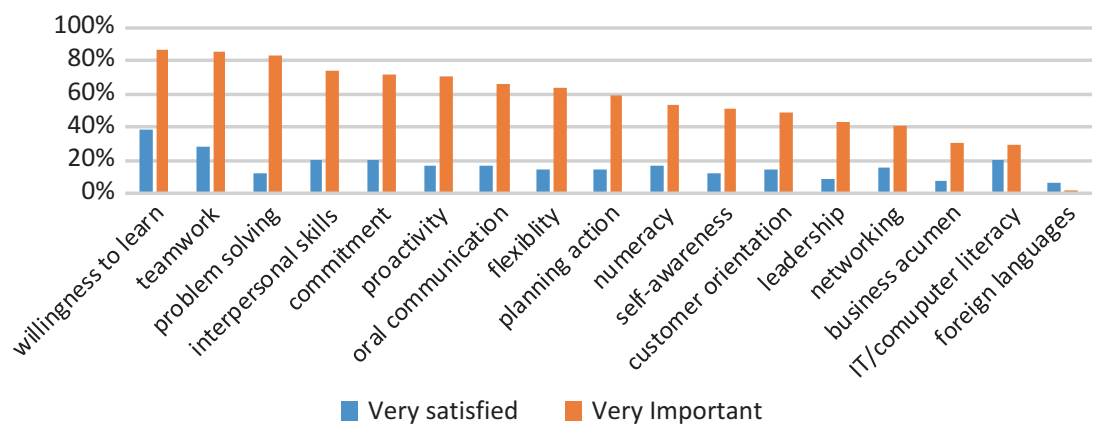

Fig. 7.1 The importance of core employability skills in South Africa. (Source: SAGRA Survey 2013, adapted from British Council 2014)

While employers feel that there is a skills gap between what is expected and the actual performance of the graduates, core employability skills are rarely taught in formal education across the world. Many universities and TVETs are still dominated by knowledge-based teaching through oneway lecturing and Africa is not an exception. Few opportunities exist for students to engage in discussion, to critique and to apply the ideas conveyed, and experience learning by doing (McCowan et al. 2016). Furthermore, these skills are expected to develop within society or in workplaces through learning by doing. However, in Africa, most enterprises are micro and small enterprises (MSEs) and do not have sufficient capacity to train their workers. Society may not have a modern work mentality, and it may be difficult to gain skills that are needed in formal waged jobs. This is why there is a growing demand for the education sector to take greater responsibility.

\section{Core Employability Skills and KaIZEN}

The development of core employability skills is actually what many company managers expect from workers when implementing Kaizen activities. Although Kaizen is known as a management tool for quality and productivity enhancement, it is also an approach used by many Japanese companies to develop their workers' capacities. For example, Shimada and Sonobe's (2017) study in Central America and the Caribbean found that Kaizen improved employee attitudes toward work. 
Kaizen activities are a continuous cycle of (1) problem identification, (2) analysis of root causes, (3) taking measures, (4) verifying the hypothesis, and (5) improving skills. The activities are usually practiced in groups and, most importantly, all of the workforce is involved. Improvement suggestions from operational staff are welcomed. Through practicing the Kaizen approach, workers accumulate skills such as problem identification/solving, teamwork, and self-sustainability. Thus, Kaizen is expected to have an impact - especially toward personal qualities (learning to learn) and process skills (teamwork and problem-solving)-as depicted in Table 7.1 .

Table 7.1 Four main core employability skills

\begin{tabular}{|c|c|c|}
\hline $\begin{array}{l}\text { Personal } \\
\text { qualities }\end{array}$ & Learning to learn & $\begin{array}{l}\text { - Willingness to learn } \\
\text { - Self-awareness } \\
\text { - Self-confidence } \\
\text { - Self-management } \\
\text { - Independence } \\
\text { - Adaptability } \\
\text { - Emotional intelligence }\end{array}$ \\
\hline Core skills & Communication & $\begin{array}{l}\text { - Competence in reading and writing } \\
\text { - Articulating ideas and thoughts } \\
\text { - Negotiation } \\
\text { - Active listening } \\
\text { - Emotional intelligence } \\
\text { - Logical thinking } \\
\text { - Use numeracy effectively }\end{array}$ \\
\hline \multirow[t]{2}{*}{ Process skills } & Teamwork & $\begin{array}{l}\text { - Ability to work cross-culturally } \\
\text { - Interact with coworkers } \\
\text { - Work toward group consensus in } \\
\text { decision-making } \\
\text { - Leadership (lead effectively, lead when } \\
\text { appropriate) } \\
\text { - Conflict management }\end{array}$ \\
\hline & Problem-solving & $\begin{array}{l}\text { - } \text { Problem identification } \\
\text { - Applying subject understanding } \\
\text { - } \text { Analyzing data and information } \\
\text { - Creative thinking } \\
\text { - Critical/logical thinking } \\
\text { - Project planning/implementation/ } \\
\text { - Prionagement } \\
\text { - Planning and time management }\end{array}$ \\
\hline
\end{tabular}


Jin (2018) argues that Kaizen activities in their basic stages can promote the formation of core capacities through learning by doing $5 \mathrm{~S}$ (Sort, Set in order, Shine, Standardize, and Sustain). He also states that these capacities are related to people's mindsets on punctuality and selfregulation and have more far-reaching impacts than the operation and maintenance of machinery, infrastructure, and performance in service delivery. The development of these core capacities is crucial for the further development of knowledge, skills, and personal qualities.

For this reason, Kaizen is highly acclaimed by many government officials in Africa. In response to their requests, projects to disseminate Kaizen have been implemented by Japan International Cooperation Agency (JICA) in eight countries: Cameroon, Ethiopia, Ghana, Kenya, South Africa, Tanzania, Tunisia, and Zambia. These projects aim to disseminate Kaizen within the private sector, as well as to enhance quality, productivity, and competitiveness.

However, what we are seeing in Africa today is something other than this. Kaizen is being introduced in universities and TVETs to enhance the employability and core skills of the students. The following sections show how Kaizen is taught in this new form.

In Sects. 5 and 6 of this chapter, the authors attempt to explore the Kaizen trainings designed to enhance core employability skills that are carried out in TVETs in Ethiopia and technical universities in South Africa. The Ethiopian case uses Yorke and Knight's (2006) categorization of core employability skills for assessment, while the South African case uses the core employability skills that are recognized by technical universities in South Africa.

\section{The Case of Ethiopia}

\subsection{Introduction}

\subsubsection{Ethiopian Context}

In Ethiopia, promotion of the manufacturing industry is regarded as a crucial strategy for accelerating economic growth in the five-year national development plan (Growth and Transformation Plan (GTP) II). The government has a vision for the country to become a light manufacturing hub in Africa during the next ten years. Multiple measures are being undertaken to achieve this, including human resource development through 
TVET. The main objective of TVET is thus "to produce lower and middle level, competent, motivated, adaptable and innovative workforces, which can contribute to poverty reduction and social and economic development through facilitating demand-driven, quality vocational education and the transfer of technology" (Federal Ministry of Education 2015). GTP II also introduced Kaizen as an approach able to bring about sustained and continuous improvements in productivity, quality, and competitiveness, as well as to minimize cost, ensure good working environments and worker safety, and promote attitudinal change.

\subsubsection{TVET Reform in Ethiopia}

TVET systems around the world have faced several criticisms. One of the best-known critiques was that by Psacharopoulos (1986, 1994), who demonstrated that both the private rate of return and the social rate of return are low in TVET compared with the general education. Likewise, TVET systems in developing countries, especially in sub-Saharan Africa, have been criticized for not responding to the needs of the labor market (AfDB/OECD 2008).

While these criticisms are still valid, the importance of TVET to national development policies is gradually being reconsidered. In a counterargument to Psacharopoulos, Bennell (1996) asserted that the social rate of return is high in TVET when considering the difference of the economic situation between students of general education and TVET in developing countries. Ogawa and Tansel (2005) also found that the employment rate of TVET graduates is higher than for those in general education in Turkey. More countries are recognizing TVET as essential for developing the human resources needed for achieving economic transformation.

In Ethiopia, TVET reformation has been implemented to meet international standards and the needs of the labor market. Competency-based training and an outcome-based system have been introduced. The Ethiopian TVET recognizes skills, knowledge, and attitudes as aspects of occupational competencies, which is a similar term to competencies for employability, as described in Sect. 2.1 (Centre of Excellence for Engineering 2015). In 2012, Kaizen courses were introduced into the Ethiopian TVET curriculum to foster good working attitudes. This means that Ethiopia believes that teaching Kaizen to TVET students will foster core employability skills that are especially related to attitudes. 
This section aims to discover how Kaizen is utilized in TVETs in Ethiopia to enhance attitudes among the competencies for employability as well as core employability skills. This case study first focuses on the features of Kaizen courses in TVET, it then examines the awareness of occupational competencies (competencies for employability) among TVET graduates, and, last, it explores whether core employability skills have been fostered through TVET Kaizen courses.

\subsection{Methods}

The survey was conducted in Addis Ababa from December 2017 to February 2018. Data were collected through questionnaires, interviews, and observations. Questionnaires were distributed randomly to a total of 200 workers engaged in micro, small, and medium enterprises (MSMEs) in the manufacturing sector and in industries such as textiles and garment, leather, automobile, metal, woodwork, and plastics. Two enumerators collected the data from industrial clusters and from SMEs in Addis Ababa. The questionnaire included questions on competencies for employability and core employability skills, as well as basic information.

This case study analyzes core employability skills using Yorke and Knight's framework (see Table 7.2). The case study focuses on core employability skills relating to the personal qualities and process skillspresented in Table 7.1 - in areas where Kaizen is believed to have had the greatest impact. To compare the differences between the graduates who had taken the Kaizen courses and those who had not, the questionnaire was distributed to 100 TVET graduates and 100 non-TVET graduates. Since the purpose of this study is to analyze Kaizen learning in TVET and/or the workplace and to compare the results with workers who have no previous Kaizen experience, we excluded the 25 respondents who had experienced Kaizen at school (not in TVET) or home or had received information about it from friends.

The respondents have been categorized into four groups according to their Kaizen experiences as follows:

- Group 1 (both TVET and at workplace): 46 respondents who took the Kaizen courses in TVET and are practicing Kaizen activities at their workplace;

- Group 2 (only in TVET): 21 respondents who took the Kaizen courses in TVET but are not practicing Kaizen at their workplace; 
Table 7.2 Comparison of perceptions on core employability skills

\begin{tabular}{|c|c|c|c|c|c|}
\hline & & $\begin{array}{l}\text { 1. Both TVET } \\
\text { \& at } \\
\text { workplace (\%) }\end{array}$ & $\begin{array}{l}\text { 2. Only } \\
\text { in TVET } \\
(\%)\end{array}$ & $\begin{array}{l}\text { 3. Only at } \\
\text { workplace } \\
(\%)\end{array}$ & $\begin{array}{l}\text { 4. No } \\
\text { Kaizen } \\
(\%)\end{array}$ \\
\hline \multirow{9}{*}{$\begin{array}{l}\text { Personal } \\
\text { qualities }\end{array}$} & Self-awareness & 23 & 22 & 16 & 18 \\
\hline & Self-confidence & 18 & 27 & 27 & 25 \\
\hline & Willingness to learn & 15 & 14 & 16 & 10 \\
\hline & Independence & 14 & 16 & 20 & 17 \\
\hline & Adaptability & 11 & 10 & 9 & 10 \\
\hline & Initiative & 8 & 6 & 5 & 4 \\
\hline & Stress tolerance & 7 & 1 & 5 & 11 \\
\hline & Reflectiveness & 4 & 4 & 3 & 5 \\
\hline & TOTAL & 100 & 100 & 100 & 100 \\
\hline \multirow{13}{*}{$\begin{array}{l}\text { Process } \\
\text { skills }\end{array}$} & Teamwork & 35 & 38 & 33 & 30 \\
\hline & Planning & 16 & 11 & 12 & 11 \\
\hline & Negotiating & 8 & 6 & 8 & 15 \\
\hline & Problem-solving & 6 & 5 & 8 & 9 \\
\hline & $\begin{array}{l}\text { Arguing for and/or } \\
\text { justifying a point of view } \\
\text { or a course of action }\end{array}$ & 6 & 2 & 6 & 5 \\
\hline & Prioritizing & 5 & 1 & 5 & 4 \\
\hline & Decision-making & 5 & 6 & 5 & 4 \\
\hline & $\begin{array}{l}\text { Applying subject } \\
\text { understanding }\end{array}$ & 4 & 9 & 6 & 5 \\
\hline & Resolving conflict & 4 & 6 & 6 & 5 \\
\hline & Acting morally & 4 & 2 & 1 & 4 \\
\hline & Ethical sensitivity & 3 & 13 & 7 & 3 \\
\hline & Commercial awareness & 3 & 2 & 3 & 4 \\
\hline & Total & 100 & 100 & 100 & 100 \\
\hline
\end{tabular}

Source: The authors

Note: Scores for priority were calculated by adding points for each level of priority: 3 points to the first priority, 2 points to the second priority, and $\mathrm{l}$ point to the third priority

- Group 3 (only at workplace): 80 respondents who are practicing Kaizen at their workplace but did not learn about Kaizen in TVET or in any other form of education; and

- Group 4 (no Kaizen): 28 respondents who do not have Kaizen experience in TVET nor were practicing it in the workplace.

Semi-structured interviews were conducted with key actors, such as the Director General of the Ethiopia Kaizen Institute (EKI), the Deputy Director of the Federal TVET Agency, the staff of the TVET institutes, 
including the instructors and Kaizen focal persons, and the staff of individual enterprises. Information on the Kaizen courses was collected from TVET-related personnel. Core employability skills required from new recruits were discussed with recruitment staff at the enterprises.

In addition, participant observations were carried out to observe the actual situation at six TVET institutes in Addis Ababa: General Winget TVET Institute, Lideta TVET Institute, Nifas Silk TVET Institute, Misrak Polytechnic College, Tegbareid TVET College, and Yeka TVET Institute.

The survey had some limitations: firstly, interviews with enterprises were conducted only with three companies and, secondly, the questionnaire was based on an opinion poll and subjective answers might be included.

\subsection{The Features of Kaizen Courses in TVET}

The curriculum of the Kaizen courses includes the Kaizen philosophy and tools that are taught in the classroom (Federal Ministry of Education 2014). These tools include 5 S (Sort, Set in order, Shine, Standardize, and Sustain), 3MU (Mura, Muri, and Muda), 4P (Policy, Procedure, People, and Plant), 4M (Material, Method, Man, and Machine), and PDCA (Plan, Do, Check, Act). The students learn Kaizen through theory and practice. The curriculum was designed by EKI, the Federal TVET Agency, and Misrak Polytechnic TVET College (one of the TVET institutes in Addis Ababa).

Kaizen training progresses through five levels, from 1 to 5 , along TVET grades. Level 1 teaches the overall concepts of Kaizen, applying the first 3S (Sort, Set in order, Shine), and organizing Junior Kaizen Promotion Teams (KPT). Level 2 teaches work safety and applying $2 S$ (Standardize and Sustain) for the first 3S. Level 3 includes eliminating and preventing waste (MUDA); Level 4 involves applying problem-solving techniques and tools; and Level 5 teaches management of the continuous improvement process (Kaizen).

Kaizen activities such as $5 \mathrm{~S}$ are integrated into the technical skills class and practiced by the students. Students also practice Kaizen while being placed in the workplace as part of cooperative training. TVET students are required to spend $70 \%$ of their time in the workplace to acquire practical skills. Furthermore, TVETs put extra effort into fostering a Kaizen culture within TVET. "Safety first" and " $5 S$ " signboards are seen everywhere. "Kaizen boards" to share information on problems, improvement points, 
and solutions are placed at the entrance of technical training classrooms. The Ethiopian TVET emphasizes practice or, in other words, learning by doing.

In support of this, training of the trainers (ToT) also seems to be contributing to fostering a Kaizen culture. TVET instructors from around Addis Ababa gather in one place to participate in ToT. During the training, TVET instructors learn how to practice 5S and PDCA cycles. The author observed groups of instructors discussing current problems of $5 \mathrm{~S}$ implementation in TVET and proposing countermeasures to improve the situation and, thus, they were practicing problem identification and analysis with each other. This provides a better understanding of Kaizen when they teach their own students.

\subsection{Findings from the Questionnaive and Interviews}

\subsubsection{Perceptions Toward the Competencies for Employability}

Figure 7.2 compares the answers of those who graduated (valid responses $=79)$ before $2012(N=15)$ and after $2012(N=64)$ to the question on what were the most useful competencies for their current job among skills, knowledge, and attitudes learned in the TVET institute/ polytechnic colleges. The results show that perceptions concerning the importance of attitudes increased from $0 \%$ to $16 \%$ after 2012 when the Kaizen courses were introduced within TVET. The responses reflect the Ethiopian government's policy toward enhancing the work readiness of TVET graduates and improving their focus on attitudes, which relates to

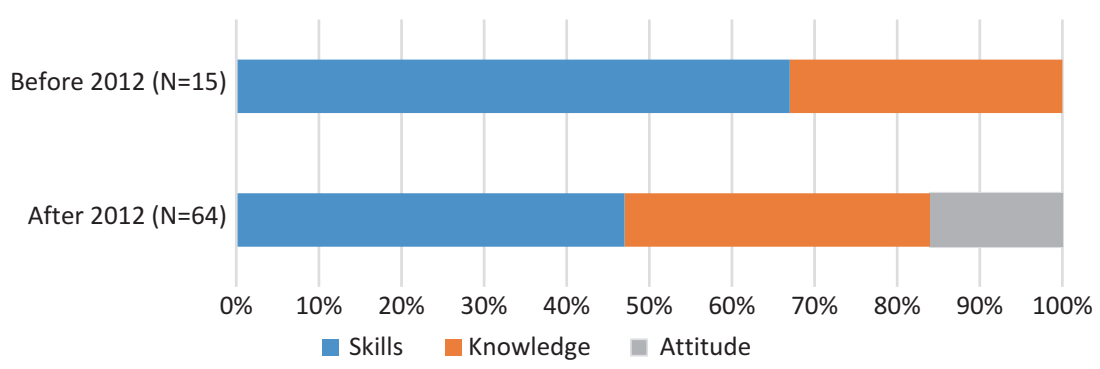

Fig. 7.2 Changes in perceptions of competencies for employability (skills, knowledge, and attitude). (Source: The authors) 
core employability skills. More graduates feel that skills relating to attitudes are also important in their jobs.

\subsubsection{Perceptions of the Core Employability Skills}

In this section, we pay attention to the core employability skills related to personal qualities and process skills explained in Table 7.1, points where Kaizen is expected to have the greatest impact.

\section{Core Employability Skills}

Table 7.2 indicates the perceptions of core employability skills from the 175 respondents. The table compares the results among the four respondent groups. They were each asked to choose the top three sub-skills needed for work from personal qualities and process skills.

Among personal qualities, sub-skills such as self-awareness, selfconfidence, willingness to learn, and independence seem to be highly regarded by all groups. Groups 1 and 2, who had taken the Kaizen courses in TVET, seem to have a greater appreciation of self-awareness than those who did not learn Kaizen in TVET. Compared to Group 4, willingness to learn is higher in Groups 1, 2, and 3, all of whom have experience of Kaizen in either TVET or/and the workplace. Compared to Group 4, the scores for willingness to learn are 5\% higher for Group 1, 4\% higher for Group 2, and 6\% higher for Group 3. On the other hand, stress tolerance is higher for the no-Kaizen group than for the Kaizen groups.

Among process skills, all four groups seem to perceive teamwork as an important core employability skill. The score is particularly high compared to other sub-skills. Scores for planning are also relatively high among the process skills. The score is higher for Kaizen in TVET and at the workplace group than the other groups. On the other hand, negotiating is higher in the no Kaizen group than in the other three groups with Kaizen experience. Problem-solving is not a focus of any groups. To the question "What do you do when a problem happens during your work?," the tendency of the responses was toward responses such as "it is not my task," "I report to my boss," and "do what I am told."

\section{Core Employability Skills Required by Enterprises}

Three employers from three enterprises in the manufacturing sector in Addis Ababa were interviewed on the core employability skills that are important in their workplace. They chose willingness to learn, initiative, self-confidence, problem-solving, teamwork, and applying subject 
understanding. All three responded that willingness to learn and problemsolving are essential when recruiting new employees. One respondent revealed that, when hiring new graduates, willingness to learn is more important than having technical skills. They perceive that technical skills can be better acquired through work rather than in TVET, especially when there is no technical course that teaches skills relating to new materials or new machinery that enterprises are handling. The respondent also stated that no one has any technical skills at the beginning; therefore, an ambitious and positive attitude toward learning is more important.

\section{Core Employability Skills Learned in the Kaizen Courses}

A question on core employability skills was also asked to TVET graduates. There were 63 valid responses from the 67 TVET graduates who had taken the Kaizen courses, of which 57 students belonged to Levels 1-3. Each respondent chose the top three sub-skills learned in the Kaizen courses from personal qualities and process skills, such as self-confidence (43 votes), self-awareness ( 36 votes), willingness to learn ( 29 votes), independence (29 votes), and process skills such as teamwork (49 votes). Participants perceive that these personal qualities are fostered mainly through Kaizen.

\subsection{Analysis}

The results regarding core employability skills show that the Kaizen courses have fostered self-confidence, self-awareness, willingness to learn, independence, and teamwork in graduates. Furthermore, the results from Table 7.2 also demonstrate that the respondents feel these four skills are important in the workplace. This section endeavors to explore the findings in detail.

The percentage of those selecting self-confidence as an important core employability skill was high for all four groups (18\%, 27\%, 27\%, and $25 \%$, respectively). However, within the four groups, the percentage for Group $\mathrm{I}$ is lower than that for other groups. This shows that, while all workers feel that self-confidence is important for work, Group 1 (both TVET and at the workplace) indicates that other skills have relatively more importance-in particular, self-awareness. Self-awareness also has a relatively high percentage in all four groups but, for Groups 1 and 2, the percentage is significantly higher compared with Groups 3 and $4(23 \%, 22 \%, 16 \%$, and $18 \%$, respectively). 
It seems that for those who implemented Kaizen in both TVET and workplace, self-awareness is more important than self-confidence. This means that the longer the Kaizen experience, the more the importance of self-awareness grows. The Cambridge English Dictionary (2019) defines "self-awareness" as good knowledge and judgment about yourself. Selfawareness involves objective self-examination in order to notice one's strengths and weaknesses using absorbed knowledge. It is understandable that Kaizen activities of plan-do-check-action (PDCA) enhance selfawareness because they force employees to check their activities. However, 57 out of 63 valid responses belonged to Kaizen Levels 1-3, in which most respondents have only studied $5 \mathrm{~S}$ and eliminating waste. This suggests that it is not the knowledge itself, but the culture that TVET is creating through implementing the Kaizen courses and emphasizing learning by doing-it is this change in culture that encourages students to self-reflect.

The perception toward the willingness to learn and independence is also relatively high in all four groups. However, for those who have experience of Kaizen in TVET or/and workplace (Groups 1, 2, and 3), there is a higher appreciation of the willingness to learn than among those who have no Kaizen experience (Group 4) $(15 \%, 14 \%, 16 \%$, and $10 \%$, respectively). On the other hand, independence has a relatively high importance for Group 3 compared with the other groups (14\%, 16\%, 20\%, and 17\%, respectively). This may suggest some differences between Kaizen experience in TVET and the workplace. Perhaps, Kaizen in the workplace places greater emphasis on the independence of the workers.

All four skills fall under the category of learning to learn in Table 7.1. This means that all four groups perceive learning to learn as an important skill for work, and that, for those who had training in Kaizen in TVET see that the training courses have fostered their skills regarding learning to learn.

Among the process skills, the percentage of those perceiving teamwork to be an important skill was significantly higher compared to other skills in all groups $(35 \%, 38 \%, 33 \%$, and $30 \%)$. It seems that those who practice Kaizen have slightly higher levels of appreciation for teamwork. Teamwork also gained the highest votes among process skills for the skills learned in TVET.

On the other hand, the importance of problem-solving received a low percentage across all groups. This skill was also not selected as skills fostered in TVET training. This outcome was rather surprising, since Kaizen is actually a process of problem-solving. 
However, understanding the Kaizen levels of the respondents clarifies the responses to the question. Many of the respondents belonged to Levels 1-3 in TVET, which provides the curriculum for basic Kaizen and does not expressly include fostering problem-solving in the contents. Problem-solving skills are developed through training in Levels 4 and 5 at PDCA. Furthermore, TVET graduates may not be placed in positions where problem-solving is needed. Perhaps they might feel that problemsolving is for managers and not for them. However, in the real world, problems exist at every level of employment and all workers are required to have some level of problem-solving skills.

In conclusion, the results show that the Kaizen courses in TVET foster learning to learn and teamwork but not problem-solving (communication was outside the scope of this study). In particular, the study confirmed that several skills related to learning to learn had been fostered through the Kaizen courses and that the graduates' appreciation of these skills is also high. This is a positive sign since learning to learn may be one of the most important skills among the core employability skills. As mentioned in Sect. 2, learning to learn is the key to self-development and life-long job security. Within a lifetime, many employees will experience different jobs in different sectors. All the aspects of learning to learn, such as selfawareness, self-confidence, and willingness to learn, will help workers transition between roles throughout their working lives. Positive outcomes arising in several layers of learning to learn indicate that the graduates' skills and perceptions of learning to learn have surely risen.

The findings of the study confirm that the Ethiopian government's policy of enhancing graduates' attitudes toward work is producing results. Enterprises also require graduates to have skills related to willingness to learn when entering the company. The three interviewees identified willingness to learn and self-confidence as skills to be required from graduates. On the other hand, since problem-solving skills are required not only in every layer of work but also in everyday life, there may be room to place greater emphasis on problem-solving skills at earlier levels.

\section{The Case of South Africa}

\subsection{Context and Policy}

South Africa's youth unemployment is exceptionally high and was reported to be $53.3 \%$ in 2017 (OECD 2018). One of the reasons is the 
relatively high wages compared to acquired skills. The National Treasury of South Africa stated in its 2011 discussion paper that "The gap between real wages and productivity is particularly high for young and lowerskilled workers, due to poor education, low skills and lack of work experience, and contributes to the problem of youth unemployment, as companies are reluctant to increase hiring when they cannot adequately assess potential" (2011, 6, National Treasury of South Africa). A study conducted by British Council in Kenya, Nigeria, Ghana, and South Africa confirms that while employers are generally satisfied with the academic skills of students, they are unsatisfied with their soft/cognitive skills (British Council 2014). Figure 7.1 shows the employers' views on the importance attached to different skills by university graduates (orange bar) and their level of satisfaction (blue).

The largest gap exists around problem-solving, teamwork, interpersonal skills, proactivity, and commitment. To address this gap, the Department of Higher Education and Training (DHET) published a White Paper for Post School Education and Training in 2013, indicating that workplace training and work-integrated learning (WIL) must be a central part of South Africa's training system. In 2014, 6-12 months of WIL became mandatory for diploma students studying at universities of technology. For TVET college students, an 18-month workplace program became mandatory. Even so, there seems to be a lack of discussion regarding workplace skills and personal qualities. To offset this, JICA's Employability Improvement Project (EIP) started to implement two days of training for third-year students of universities of technology before they enter the 6-12 months of the WIL program.

\subsection{Employability Improvement Training}

Employability Improvement Training is a two to three-day training program offered in seven universities in South Africa to prepare students for the WIL program. The training is positioned at an introductory stage of the WIL program, and funding assistance for activities is provided by the National Skills Fund (NSF). So far, 4164 students and 45 lecturers have participated in this training. The curriculum was developed by an expert team dispatched from JICA to implement the Employability Improvement Project (EIP). The training is aimed at developing seven skills that the project has identified as core employability skills: self-management, communication, teamwork, leadership, problem identification/solving, 
creativity, and critical/logical thinking. Training in the skills is provided through half-day lectures and a day and a half of hands-on practice.

The project identified these skills through an enterprise survey. Note that while some skills - such as communication, teamwork, and problemsolving-are listed as core employability skills in Table 7.1, other skills are also highlighted, including self-management, leadership, creativity, and critical/logical thinking. In South Africa, the market requires skills other than the four broad-based skills but, if you look at Table 7.1 carefully, you will notice that these skills also relate to the four broad-based skills. For example, self-management contributes to learning to learn, leadership to teamwork and creativity, and critical/logical thinking to problemsolving skills.

The curriculum is divided into four modules based on $3 \mathrm{i}$ (implementation, improvement, and innovation). The program was initially designed to be disseminated over five days but is currently delivered in two to three days due to constraints on the availability of students and lecturers.

The most distinctive feature of employability improvement training is that students experience assembling toy-trucks three times while practicing Kaizen and all the seven skills that they learned in the half-day of lectures. In their first round, the students are instructed to assemble the trucks by themselves or in a group of two. They are handed out a manual that indicates the quantity of each of the necessary parts and the exact specifications of the truck. It usually takes them around 1.5 hours to assemble the truck, in their first attempt. Many would have to do this a couple of times because they failed the quality checks.

In the second round, the students are put together in groups of eight to ten. Each team decides who will play the role of a supervisor, the parts shop staff, and the assembly line staff. This time, they are instructed to assemble 10 trucks within 40 minutes. In the third round, the students are encouraged to be more creative and see whether they can improve their productivity and defect rate. Before each round starts, the students are given planning time. During this time, they review the previous round and discuss how they can improve productivity and quality in the next round.

The Nissan Motor Corporation originally developed this as a hands-on learning program for schoolchildren to experience the joy of Monozukuri ${ }^{1}$ and Kaizen as one of their Corporate Social Responsibility (CSR) activities (Nissan Motor Corporation 2018). The Employability Improvement Project got permission to use their models and modified the program to make it suitable for university students as a learning kit. 


\subsection{Methods}

The author visited Tshwane University of Technology and Durban University of Technology in February 2018 and observed training conducted with lecturers and students. The author conducted interviews with two Japanese experts, two EIP coordinators/trainers, seven lecturers, and five students in their fourth year of the Bachelor of Technology (B Tech). The interviews were conducted in a semi-structured way. Another four students responded via e-mail questionnaire. Additionally, participant observation was conducted with the EIP training done at both universities.

Section 6.4 will discuss the findings from participant observation of EIP, while Sect. 6.5 will discuss the findings and analysis from the survey.

\subsection{Participant Observation of EIP Training}

\subsubsection{Observations from the First Round}

It is amazing to see student expressions change during the training. Students who seemed to be overly confident during the lecture, boasting that they will be the first to finish, become suddenly serious while assembling the truck. Their first attempt in assembling the "toy truck" is not going so well. Somehow, the parts being used do not allow them to assemble the truck as the instructions specify. They need to change the parts to the right ones.

One lecturer who took the course as per the instruction from the school management discussed this experience "I am teaching engineering to students so I thought that it (assembling a truck) would be easy. Once I started assembling one, it was not easy. I found out that I needed to read the instructions more carefully and that the details are important. It was a learning experience for me too." The instructions are written in a way that, unless the trainees read them carefully, they miss out on key information, so they struggle during the assembly process. The Japanese experts explained that the first round is designed to create just such a problem: it is a simulation of real life. Miscommunication and misunderstandings derived from incomplete key information occur every day-the important question is what you do about it.

\subsubsection{Observations from the Second Round}

In the second round, assembly time improved dramatically, and most teams had fewer defects. In this round the trainees were working in teams. 
Before the assembly starts, they share their previous experiences, analyze the problems that occurred, and discuss how they can avoid them. Groups that emphasize teamwork achieve the best results. Some "supervisors" are able to react to the struggles the "operators" are facing and help them out. Others just run about not knowing what to do. Some "operators" help others when their work finishes early. This is all a working experience to shorten the delivery time and to produce a high-quality truck.

In the interviews, several students said that they had never had an opportunity to work in teams like this before. They wished that they had more opportunity like this in regular classes. Furthermore, working in teams seems to help the students realize what their strengths and weaknesses are. One lecturer commented that students often lack confidence because they have not appreciated whether or not they are good at a task.

A student's comment verified this lecturer's comments: "The training helped me realize the importance of listening to others. Sometimes, I am stubborn. Working as a team helped me look at things more objectively. I learned to be patient with other people. Taking a leadership role is not hard for me-being supportive is. I feel that I really want to change and improve. Teamwork has everything to do with it."

\subsubsection{Observations from the Third Round}

The third round is an attempt to enhance productivity, teamwork, and creativity. Rie Shinozaki from JICA said that "While doing the assembly work two or three times, the students gradually began to develop their own ideas and started to make more finished products with higher efficiency. This includes cleaning up the desk that serves as their work area and creating an assembly line system for the parts" (JICA 2018). The experience of thinking for themselves rather than just doing things according to the instructions-like when the students implemented countermeasures after finding traps in the manual-changes the behavior of young people in the places where they work.

\subsection{Findings from the Survey}

\subsubsection{Results of the Survey}

Nine students responded to the survey on how EIP training impacts the development of the seven core employability skills (Table 7.3). 
Table 7.3 Impact of EIP training in seven core employability skills

\begin{tabular}{llllll}
\hline & $\begin{array}{l}\text { Change in } \\
\text { daily } \\
\text { action }\end{array}$ & $\begin{array}{l}\text { Took action } \\
\text { couple of } \\
\text { times after } \\
\text { the training }\end{array}$ & $\begin{array}{l}\text { Adapted the } \\
\text { way of thinking } \\
\text { but have not } \\
\text { acted upon it }\end{array}$ & $\begin{array}{l}\text { Acknowledged } \\
\text { the concept }\end{array}$ & $\begin{array}{l}\text { No } \\
\text { change } \\
\text { at all }\end{array}$ \\
\hline $\begin{array}{l}\text { Learning to learn } \\
\text { Self-management }\end{array}$ & 5 & 1 & 3 & 0 & 0 \\
$\begin{array}{l}\text { Communication } \\
\text { Teamwork }\end{array}$ & 5 & 2 & 0 & 2 & 0 \\
$\quad 3$ & 4 & 2 & 0 & 0 \\
$\begin{array}{l}\text { Leadership } \\
\text { Problem }\end{array}$ & 1 & 3 & 4 & 1 & 0 \\
identifying/solving & 5 & 1 & 2 & 1 & 0 \\
$\quad \begin{array}{l}\text { Critical/logical } \\
\text { thinking }\end{array}$ & 7 & 2 & 0 & 0 & 0 \\
Creativity & 2 & 1 & 1 & 5 & 0 \\
\hline
\end{tabular}

Source: The authors

Six out of nine students indicated that they had experienced changes in self-management, seven in communication, another seven in teamwork, four in leadership, six in problem-solving, nine in critical/logical thinking, and three in creativity. The results of the survey show that more students felt the training had fostered their critical/logical thinking. Substantial numbers of students also felt that the training had an impact on selfmanagement, communication, and teamwork. The results varied with regard to leadership and creativity.

\subsubsection{Analysis}

With the limitations of the respondents, it is hard to determine whether or not the students acquired the intended skills. Furthermore, skills are usually acquired over time. Students may need more practice to be able to deploy them in an effective way. However, it might be concluded that the training had some impact on the awareness of the skills, especially selfmanagement, communication, teamwork, problem identification/solving, and critical/logical thinking. It would have been interesting to explore results related to self-awareness; however, this was not included in the survey items. The comments of students in the participant observations provide some indication that the training might have had some impacts on self-awareness. 
Furthermore, the survey results also demonstrate that there are some skills that students have had more opportunities to exhibit than others. For instance, students may have greater opportunities to utilize skills such as teamwork, communication, and logical thinking, rather than leadership and creativity. All respondents are four-year B Tech students who have experienced internships. Employers may not expect interns to display their leadership or creativity.

\section{Conclusions}

While Kaizen is often implemented to enhance worker's core employability skills, both the Ethiopian and South African cases demonstrate how Kaizen training can be applied in the education sector. The Ethiopian government has been emphasizing the need to change the attitudes of its people and incorporates Kaizen in the TVET curriculum to aid this. In South Africa, employability improvement training is being implemented to enhance seven core employability skills and preparedness to work.

In both cases, the practice of Kaizen-or in other words learning by doing - is emphasized. TVET in Ethiopia has made great efforts into creating a Kaizen culture within TVET. In the case of South Africa, Kaizen is practiced through assembling toy-trucks. These are, in some ways, simulations of the workplace. The South African case shows that Kaizen activities are a combination of learning to learn, communication, teamwork, and problem-solving experiences.

Through continuous improvement activities and self-assessment observed in the three rounds of truck assembly in EIP training, students do become aware of their faults as well as their strengths (self-awareness). They question themselves about ways that they can improve. This question is itself a way of learning to learn. The students discuss with others their theories on how to improve (communication and teamwork). They implement their theories and assess the results (problem-solving).

Furthermore, in the case of Ethiopia, the survey results confirmed that the Kaizen courses foster learning to learn (self-confidence, self-awareness, and willingness to learn) and teamwork. To see whether the courses impacted problem-solving, we need more respondents from levels 4 to 5, where problem-solving is taught. The survey also shows that Kaizen courses have had an impact on the mindsets of students. Awareness toward learning to learn, especially self-awareness and willingness to learn, is higher for those who had Kaizen trainings in TVET. 
While recognition of core employability skills is slowly increasing in Africa, penetration is still minimal. Many skills development projects are targeted more toward subject-specific knowledge and skills. The fact that there is no unified understanding of what core employability skills are and the lack of established curricula to enhance core employability skills may also contribute to low penetration. Workplace-based programs that focus on non-cognitive skills are known to be effective in promoting workrelated skills. This chapter proposes that Kaizen should include activities in the school/TVET curriculum as one option to enhance the core employability skills of students.

These experiences may be much more precious in developing countries compared to more advanced economies where many other options exist. Students in advanced countries can prepare for work through internships, extracurricular activities, and volunteer work. These experiences are undoubtedly valuable for developing core employability skills. However, in many cases in Africa, getting an internship is itself a challenge.

Finally, additional studies are needed to confirm whether Kaizen training in TVET and technical universities has really enhanced core employability skills among graduates and whether there has been any increase in satisfaction from the employers. Further studies are also needed to understand the best way to incorporate the development of core employability skills into school curriculums in Africa.

\section{Note}

1. Monozukuri literally means "production" in Japanese. The broader term encompasses Japanese spirit towards production.

\section{REFERENCES}

AfDB/OECD. 2008. African Economic Outlook. African Development Bank Centre of the Organisation for Economic Co-operation and Development. France: OECD Publication.

Aring, Monika. 2012. Skills Gaps Throughout the World: An Analysis for UNESCO Global Monitoring Report 2012. Paper Commissioned for the EFA Global Monitoring Report 2012.

Bennell, P. 1996. Using and Abusing Rates of Return: A Critique of the World Bank's 1995 Education Sector Review. International Journal of Educational Development 16 (3): 235-248. 
Brewer, L. 2013. Enhancing Youth Employability: What? Why? and How? Guide to Core Work Skills. Geneva: International Labour Office, Skills and Employability Department, ILO.

British Council. 2014. Can Higher Education Solve Africa's Job Crisis? Understanding Graduate Employability in Sub-Saharan Africa, Going Global 2014. https://www.britishcouncil.org/sites/default/files/graduate_employability_in_ssa_final-web.pdf

Cambridge Dictionary. 2019. Self-awareness. Accessed May 9, 2019. https://dictionary.cambridge.org/dictionary/english/self-awareness

Centre of Excellence for Engineering. 2015. Module Apply 3S Level I. Based on Occupational Standard (OS). Addis Ababa: Ethiopian TVET-System.

Cloutier, Marie-Helene, C. Reinstadtler, and Isabel Beltran. 2011. Making the Grade: Assessing Literacy and Numeracy in African Countries. DIME Brief. Washington, DC: World Bank

Federal Ministry of Education. 2014. Occupational Standard NTQF Level. Addis Ababa: Federal Democratic Republic of Ethiopia.

- 2015. Education Sector Development Programme V (ESDP V). Addis Ababa: Federal Democratic Republic of Ethiopia.

Hillage, Jim, and E. Pollard. 1998. Employability: Developing a Framework for Policy Analysis. Labour Market Trends 107: 83-84.

International Labour Organisation (ILO). 2000. Training for Employment: Social Inclusion, Productivity Report V. Geneva: ILO.

- 2004. R195 Human Resources Development Recommendation, Geneva, 92nd ILC session. https://www.ilo.org/dyn/normlex/en/f?p=NORMLEXP UB:12100:0::NO::P12100_ILO_CODE:R195

JICA. 2018. South Africa-Rainbow of Promise: Looking Ahead to the Future. JICA's World, July. https://www.jica.go.jp/english/publications/j-world/ 1807_01.html.

Jin, K. 2018. Role of Kaizen in Japan's Overseas Development Cooperation. In Applying the Kaizen in Africa: A New Avenue for Industrial Development, ed. K. Otsuka, Chap. 2. New York: Palgrave Macmillan.

McCowan, Tristan, Melanie Walker, Sam Fongwa, Ibrahim Oanda, Daniel Sifuna, Segun Adedeji, Stephen Oyebade, Eric Daniel Ananga, Vincent AdzahlieMensah, and Emmanuel Tamanja. 2016. Universities, Employability and Inclusive Development Project (2013-2016). London: British Council.

Ministry of Economy, Trade, and Industry of Japan (METI). 2006. Shakaijinkisoryoku ni kansuru kenkyukai 'chukan torimatome [Interim Report of Study of Core Employability Skills]. Tokyo: METI.

. 2007. Shakaijinkisoryoku' ikusei no susume. shakaijinkisoryokuikusei puroguramu no fukyu wo mezashite [Recommendations on Fostering Core Employability Skills. Towards Promoting Program on Core Employability Skills]. Tokyo: METI. 
National Treasury of South Africa. 2011. Confronting Youth Unemployment: Policy Options for South Africa. Discussion Paper for Public Comment. http://www.treasury.gov.za/documents/national\%20budget/2011/ Confronting\%20youth\%20unemploymen\%20-\%20Policy\%20options.pdf

Nissan Motor Cooperation. 2018. https://www.nissan-global.com/JP/ CITIZENSHIP/MONOZUKURI/program.html

Ogawa, K., and A. Tansel. 2005. Transition from Education to Labor Market in Turkey. Journal of International Cooperation Studies 12 (3): 113-143.

Organization for Economic Cooperation and Development (OECD). 2018. Unemployment Rate (indicator). https://doi.org/10.1787/997c8750-en.

Psacharopoulos, G. 1986. Curriculum Diversification, Cognitive Achievement and Economic Performance: Evidence from Colombia and Tanzania. Paper Presented at the Conference on Vocationalizing General Education, Institute of Education, University of London, May 7-8.

- 1994. Returns to Investment in Education: A Global Update. World Development 22 (9): 1325-1343.

Shimada, G, and T. Sonobe. 2017. Impacts of Kaizen Management on Workers: Evidence from the Central America and Caribbean Region. Paris: OECD.

United Nations (UN). 2001. Recommendations of the High-Level Panel of the Youth Employment Network. New York: United Nations General Assembly, September 28.

United Nations, Department of Economic and Social Affairs, Population Division. 2019. World Population Prospects 2019, Volume I: Comprehensive Tables (ST/ESA/SER_A/426).

World Bank. 2019. The Changing Nature of Work. World Development Report Working Draft. May 14, 2018. New York: World Bank. http://documents. worldbank.org/curated/en/816281518818814423/pdf/2019-WDRReport.pdf

Yorke, M. 2006. Employability in Higher Education: What it Is-What it is Not, Learning and Employability Series One. York: The Higher Education Academy. Yorke, M., and P. Knight. 2006. Embedding Employability into the Curriculum, Learning and Employability Series One. York: The Higher Education Academy. 
Open Access This chapter is licensed under the terms of the Creative Commons Attribution 4.0 International License (http://creativecommons.org/licenses/ by $/ 4.0 /$ ), which permits use, sharing, adaptation, distribution and reproduction in any medium or format, as long as you give appropriate credit to the original author(s) and the source, provide a link to the Creative Commons licence and indicate if changes were made.

The images or other third party material in this chapter are included in the chapter's Creative Commons licence, unless indicated otherwise in a credit line to the material. If material is not included in the chapter's Creative Commons licence and your intended use is not permitted by statutory regulation or exceeds the permitted use, you will need to obtain permission directly from the copyright holder.

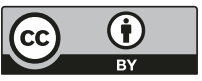

